\title{
Metacestodes of Glossocercus auritus (Cyclophyllidea, Gryporhynchidae) in Poecilia reticulata (Pisces, Poeciliidae) from Brazil
}

\author{
Metacestoides de Glossocercus auritus (Cyclophyllidea, Gryporhynchidae) \\ em Poecilia reticulata (Pisces, Poeciliidae) no Brasil \\ Hudson Alves Pinto'; Alan Lane de Melo ${ }^{1 *}$
}

\begin{abstract}
${ }^{1}$ Laboratório de Taxonomia e Biologia de Invertebrados, Departamento de Parasitologia, Instituto de Ciências Biológicas, Universidade Federal de Minas Gerais - UFMG
\end{abstract}

Received December 7, 2010

Accepted February 7, 2011

\begin{abstract}
Studies on fish parasites in Pampulha dam, Belo Horizonte, Minas Gerais, Brazil, found specimens of Poecilia reticulata Peters, 1859 harboring natural infection by larval stages of tapeworms. A total of 250 specimens of $P$. reticulata were collected and analyzed between February and August 2010, of which 23 were found infected (prevalence 9.2\%) with one metacestode each (mean intensity 1 , mean abundance 0.09 ). The analyses of the parasites, particularly the morphology of rostellar hooks, made it possible to identify Glossocercus auritus (Rudolphi, 1818). This is the first report of G. auritus metacestode in South America and P. reticulata is a newly known host for this parasite.
\end{abstract}

Keywords: Cestodes, Poecilia reticulata, Glossocercus auritus, new host, fish parasites.

\section{Resumo}

Em estudo da helmintofauna de peixes oriundos da represa da Pampulha, Belo Horizonte, Minas Gerais, Brasil, exemplares de Poecilia reticulata Peters, 1859 foram encontrados naturalmente infectados por larvas de cestóides. De 250 espécimes de P. reticulata coletados e analisados entre fevereiro e agosto de 2010, 23 (prevalência de infecçáo 9,2\%) apresentavam-se infectados por um metacestóides cada (intensidade média 1, abundância média 0,09). A análise dos parasitos, em especial a morfologia dos acúleos rostelares, permitiram a identificação de Glossocercus auritus (Rudolphi, 1818). Este é o primeiro registro de metacestóide de G. auritus para a América do Sul, sendo P. reticulata um novo hospedeiro conhecido para o parasito.

Palavras-chave: Cestóides, Poecilia reticulata, Glossocercus auritus, novo hospedeiro, parasitos de peixe.

\section{Introduction}

The Gryporhynchidae (Cestoda: Cyclophyllidea) are intestinal tapeworms parasites of fish-eating birds, and their larval forms (metacestodes) are found infecting over a hundred freshwater fish species, mainly in the Palearctic region (reviewed by SCHOLZ et al., 2004). Although several species of these cestodes have been reported, studies relating to species composition and distribution of these parasites are scarce, and for a significant percentage of gryporhynchid species, their metacestodes and life cycle remain unknown. In South America, and specifically in Brazil, the only species for which metacestodes are known is Valipora campylancristrota (Wedl, 1855), found in Prochilodus lineatus

\footnotetext{
*Corresponding author: Alan Lane de Melo

Laboratório de Taxonomia e Biologia de Invertebrados,

Departamento de Parasitologia, Instituto de Ciências Biológicas,

Universidade Federal de Minas Gerais - UFMG, CP 486,

CEP 30123-970, Belo Horizonte - MG, Brazil;

e-mail: aldemelo@icb.ufmg.br
}

(Valenciennes, 1836), Pimelodus maculatus Lacépède, 1803, and Hoplosternum littorale (Hancock, 1828) in the State of Paraná, Southern Brazil (REGO et al., 1999; TAKEMOTO et al., 2009). Recently, Valipora sp. and another unidentified metacestodes were found in Prochilodus argenteus Spix \& Agassiz, 1829 in the State of Minas Gerais (MONTEIRO et al., 2009).

In the present study, metacestodes of Glossocercus auritus (Rudolphi, 1818) are reported for the first time in Poecilia reticulata Peters, 1859 in Brazil.

\section{Material and Methods}

The fish specimens were collected with the aid of a scoop net during monthly sampling conducted in Pampulha dam $\left(19^{\circ} 51^{\prime} 77^{\prime \prime} S\right.$ and $\left.43^{\circ} 58^{\prime} 54^{\prime \prime} \mathrm{W}\right)$, an artificial eutrophic waterbody located in the northern region of the city of Belo Horizonte, from 
February to August 2010. The specimens collected were placed in plastic containers with water and transported alive to the laboratory. Then they were measured with a caliper, killed by decapitation in accordance with the recommendations from the local animal experimentation ethics committee (CETEA/UFMG), dissected and examined for parasites under a stereomicroscope.

When the cysts obtained were removed intact, they were measured. The larvae were then mechanically excysted and transferred to Petri dishes containing saline solution $(0.85 \%$ $\mathrm{NaCl}$ ). They were then flattened under soft pressure between glass slides and fixed in Railliet-Henry solution at $70{ }^{\circ} \mathrm{C}$. The parasites were stained with acetic alum carmine, dehydrated in an alcohol series, cleared in beechwood creosote and mounted as permanent preparations in Canada balsam.

Additionally, scolices of some specimens were squashed and the hooks obtained were mounted in non-permanent preparations after addition of lactophenol. A morphological analysis was conducted using a light microscope, and specimens were measured through an eyepiece graduated in millimeters. Drawings of the rostellar hooks were made with aid of a camera lucida and photographic documentation was obtained using a digital camera coupled to the microscope.

Some larvae obtained were also used to experimentally infect mice (Mus musculus Linnaeus, 1758), young chicken (Gallus gallus domesticus (Linnaeus, 1758)), and young and adult pigeons (Columba livia Gmelin, 1789). Metacestodes were force-fed to these hosts and, fifteen days after infection, the hosts were killed by cervical dislocation and examined for parasites.

The taxonomic identification was based on morphological criteria, especially the rostellar hook morphology (number, shape and size), as recommended by several authors (BONA, 1994; SCHOLZ; SALGADO-MALDONADO, 2001; SCHOLZ et al., 2002a, 2004).

Ecological terms were used as proposed by Bush et al. (1997). The specimens studied were deposited in the collection of the Laboratory of Taxonomy and Biology of Invertebrates, at the Department of Parasitology, Universidade Federal de Minas Gerais (UFMG) (accession number $6157 \mathrm{a}-\mathrm{j}$ ).

\section{Results and Discussion}

Of 250 specimens of $P$. reticulata with mean length $2.1 \mathrm{~mm}$ (range: $1.2-4 \mathrm{~mm}$ ) examined, 23 were found naturally infected by metacestodes. Through morphological examination, the following species was identified:

\section{Glossocercus auritus (Rudolphi, 1818), (Figure 1).}

Synonymous: Taenia aurita; Parvitaenia aurita; Anomotaenia aurita.

Host: Poecilia reticulata Peters, 1859 - new host record.

Site of infection: Mesentery.

Locality: Pampulha dam, Belo Horizonte, Minas Gerais, Southeastern Brazil - new geographical record.

Prevalence: 9.2\% (23/250).

Mean intensity: 1.

Mean abundance: $0.09 \pm 0.3$.
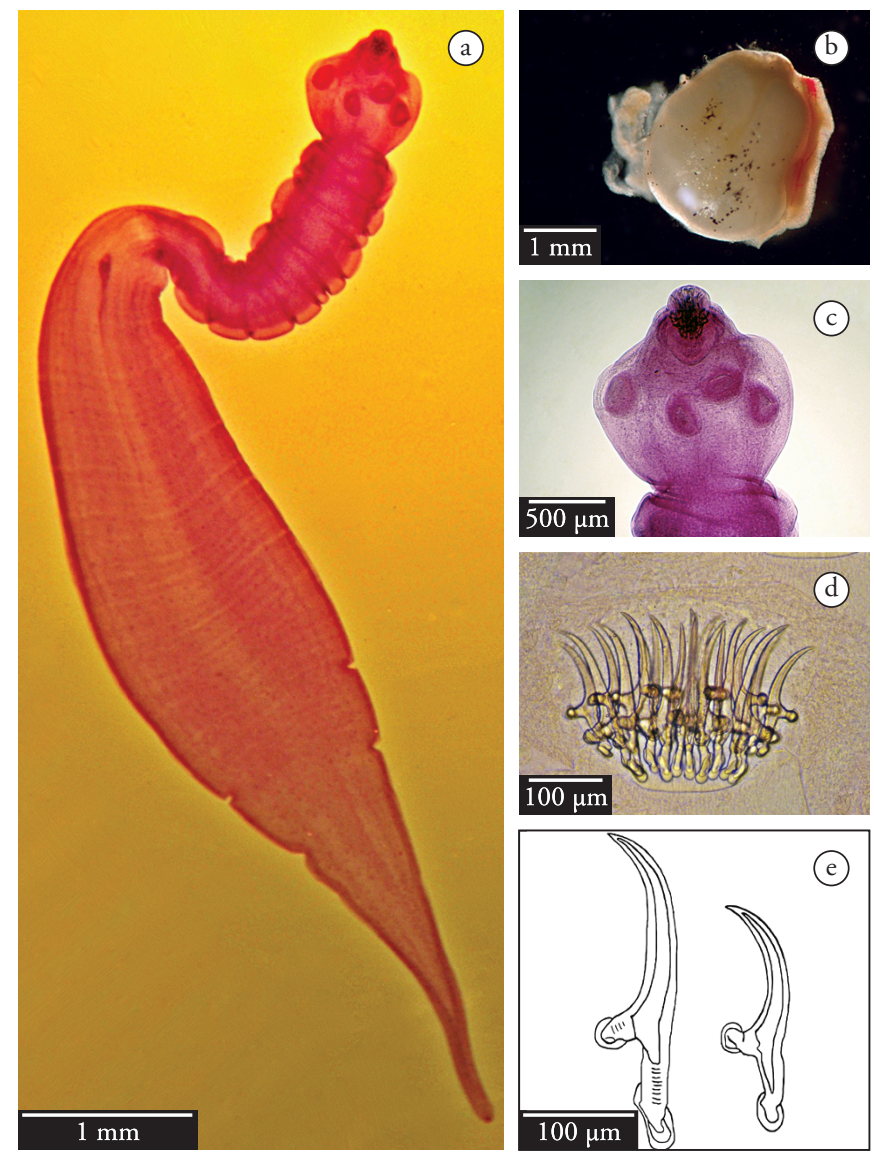

Figure 1. Glossocercus auritus - Metacestodes found in Poecilia reticulata from Pampulha dam, Belo Horizonte, Minas Gerais, Brazil. a) excysted larvae; b) whole cyst; c) detail of the scolex; d) detail of the armed rostellum; e) distal hook (left) and proximal hook (right).

Experimental infection: unsuccessful.

Morphological description: Based on 10 specimens. Larvae encysted in oval shaped cysts measuring 3.1 (2.6-4.0) $\mathrm{mm}$ long $\mathrm{x}$ 2.6 (2.2-3.0) mm wide (Figure 1b). After mechanical excystation, the larvae showed extension and contraction movements of the body. Some of them had an evaginated scolex. The parasite was relatively very large (Figure 1a); its body was formed by an elongated scolex measuring $3.25 \pm 0.86(1.98-5.02) \mathrm{mm}$ long $\mathrm{x}$ $1.04 \pm 0.17(0.77-1.22) \mathrm{mm}$ wide, and a posterior tapered part measuring $10.38 \pm 2.75(6.85-15.71) \mathrm{mm}$ long x $1.71 \pm 0.39$ (1.21-2.28) mm wide (Figure 1b). The scolex (Figure 1c) showed four spherical to oval suckers measuring $259 \pm 27$ (205-321) $\mu \mathrm{m}$ long x $192 \pm 16(150-225) \mu \mathrm{m}$ wide, and a muscular rostellum. The rostellar pouch was $262 \pm 13(239-273) \mu \mathrm{m}$ long x $277 \pm$ 28 (239-341) $\mu \mathrm{m}$ wide. It had a rostellum armed with 20 hooks arranged in two crowns of 10 hooks each (Figure 1d). The hooks (Figure 1e) presented massive sclerification (epiphyseal thickening) of the handle and guard. The distal hook had $251 \pm 5$ (246-259) $\mu \mathrm{m}$ with a $149 \pm 7(137-164) \mu \mathrm{m}$ blade, a $105 \pm 6(96-116) \mu \mathrm{m}$ handle and a blade/handle ratio of 1.41 (1.29-1.64). The proximal hook had $182 \pm 6(171-191) \mu \mathrm{m}$ with a $100 \pm 3(96-102) \mu \mathrm{m}$ blade, a $84 \pm 3(82-89) \mu \mathrm{m}$ handle and a blade/handle ratio of 1.20 (1.15-1.25). A comparison between the measurements of 
Table 1. Morphometric comparison between rostellar hook measurements of metacestodes of Glossocercus spp. obtained in the present study and those reported by other authors (in micrometers).

\begin{tabular}{|c|c|c|c|c|c|}
\hline & \multicolumn{2}{|c|}{ Glossocercus auritus } & \multicolumn{2}{|c|}{ Glossocercus caribaensis } & \multirow{2}{*}{$\begin{array}{c}\text { Glossocercus cyprinodontis } \\
\text { Scholz et al. (2004) }\end{array}$} \\
\hline & Present study & Scholz et al. (2001) & Scholz et al. (2001) & Scholz et al. (2002b) & \\
\hline Locality & Brazil & Mexico & Mexico & USA & USA \\
\hline Host & Poecilia reticulata & $\begin{array}{l}\text { Poecilia sphenops } \\
\text { Poeciliopsis gracilis }\end{array}$ & $\begin{array}{l}\text { Cichlasoma urophthalmus } \\
\text { Fundulus persimilis }\end{array}$ & $\begin{array}{l}\text { Fundulus heteroclitus } \\
\text { Fundulus majalis }\end{array}$ & Cyprinodon variegatus \\
\hline \multicolumn{6}{|l|}{ Distal hook } \\
\hline Length & $246-259$ & $242-267$ & $189-211$ & $186-205$ & $180-195$ \\
\hline Blade/Handle Ratio & $1.29-1.64$ & $1.56-1.89$ & $1.20-1.61$ & $1.42-1.73$ & $1.30-1.49$ \\
\hline \multicolumn{6}{|l|}{ Proximal hook } \\
\hline Length & $171-191$ & $189-202$ & $134-146$ & $124-143$ & $129-141$ \\
\hline Blade & $96-102$ & $93-115$ & $66-82$ & $68-83$ & $79-86$ \\
\hline Handle & $82-89$ & $83-96$ & $62-75$ & $56-68$ & $62-74$ \\
\hline
\end{tabular}

rostellar hooks of the parasites in the present study and in others Glossocercus spp. metacestode reports is presented in the Table 1.

At least eight species of Glossocercus Chandler, 1935 have already been described (PICHELIN et al., 1998), and metacestodes of three of them ( $G$. aurita, G. cyprinodontis Chandler, 1935, G. caribaensis (Rysavy and Macko, 1973)) are known. Metacestodes of these species differ mainly in terms of morphology and hook measurements, which are significantly larger in $G$. auritus (Table 1).

Glossocercus auritus, a species described from adult parasites recovered from Little Blue Heron (Egretta caerulea (Linnaeus, 1758)) in Brazil, is considered to be the type species of the genus, with regard to adult specimens (BONA, 1994). Since its description, this parasite has been found infecting Ardea alba Linnaeus 1758, A. herodias Linnaeus, 1758, E. tricolor (Statius Muller, 1776), E. thula (Molina, 1782), Nyctanassa violacea (Linnaeus, 1758) in Cuba, Mexico and Nicaragua (SCHOLZ et al., 2001; ORTEGAOLIVARES et al., 2008). Two of these ardeids, $A$. alba and E. thula, have been found at Pampulha dam (PIMENTA et al., 2007), and can thus be considered potential definitive hosts of $G$. auritus in this locality.

The larval form of $G$. auritus, in turn, was found for the first time in Poecilia sphenops Valenciennes in Cuvier \& Valenciennes, 1846, and Poeciliopsis gracilis (Heckel, 1848) in Mexico (SCHOLZ et al., 2001), and later in Poecilia catemaconis Miller, 1975, Poecilia mexicana Steindachner, 1863, and Astyanax fasciatus (Cuvier, 1819) in that same country (SCHOLZ; SALGADO-MALDONADO, 2001; SCHOLZ et al., 2004; SALGADO-MALDONADO et al., 2005). The morphology and measurements of parasites obtained from $P$. reticulata in the present study are consistent with data presented by these authors.

In the present study, attempts to recovery adult parasites from vertebrate host were unsuccessful after experimental infection, and their absence in the hosts evaluated could be attributable to a potential host specificity of this cestode for ardeids. In fact, there are no records of experimental or natural infection in mammals and non-ardeid birds.
The diversity and life cycle of gryporhynchid parasites of Brazilian fishes need further studies to improve the knowledge about these biological interactions. This is the first report on metacestodes of $G$. auritus in Brazil and South America, and P. reticulata is a new intermediary host recorded for this parasite.

\section{References}

BONA, F. V. 1994. Family Dilepididae Railliet \& Henry, 1909. In: KHALIL, L. F.; JONES, A.; BRAY, R. A. (Eds.). Keys to the Cestode Parasites of Vertebrates. Wallingford Oxon: CAB International, 1994. p. 443-554.

BUSH, J. O. et al. Parasitology meets ecology on its own terms: Margolis et al. revisited. Journal of Parasitology, v. 83, n. 4, p. 575-583, 1997. PMid:9267395. http://dx.doi.org/10.2307/3284227

MONTEIRO, C. M. et al. Ecological parameters of the endohelminths in relation to size and sex of Prochilodus argenteus (Actinopterygii: Prochilodontidae) from the upper São Francisco river, Minas Gerais, Brazil. Zoologia, v. 26, n. 4, p. 753-757, 2009.

ORTEGA-OLIVARES, M. P. et al. Tapeworms (Cestodes: Gryporhynchidae) of fish- eating birds (Ciconiiformes) from Mexico: new host and geographical records. Comparative Parasitology, v. 75, n. 2, p. 182-195, 2008. http://dx.doi.org/10.1654/4346.1

PICHELIN, S.; CRIBB, T. H.; BONA, F. V. Glossocercus chelodinae (MacCallum, 1921) n. comb. (Cestoda: Dilepididae) from freshwater turtles in Australia and a redefinition of the genus Bancroftiella Johnston, 1911. Systematic Parasitology, v. 39, n. 3, p. 165-181, 1998. http://dx.doi.org/10.1023/A:1005922311904

PIMENTA, F. E.; DRUMMOND, J. C. P.; LIMA, A. C. Aves aquáticas da Lagoa da Pampulha: seleçáo de hábitats e atividade diurna. Lundiana, v. 8, n. 2, p. 89-96, 2007.

REGO, A. A.; CHUBB, J. C.; PAVANELLI, G. C. Cestoda in South American freshwater teleost fishes: keys to genera and brief description of species. Revista Brasileira de Zoologia, v. 16, n. 2, p. 299-367, 1999. http://dx.doi.org/10.1590/S0101-81751999000200003 
SALGADO-MALDONADO, G. et al. Helminth parasites in freshwater fish from the Papaloapan river basin, Mexico. Parasitology Research, v. 96, n. 2, p. 69-89, 2005. PMid:15812673. http://dx.doi.org/10.1007/ s00436-005-1315-9

SCHOLZ, T.; SALGADO-MALDONADO, G. Metacestodes of the family Dilepididae (Cestoda: Cyclophyllidea) parasitising fishes in Mexico. Systematic Parasitology, v. 49, n. 1, p. 23-40, 2001. PMid:11389328. http://dx.doi.org/10.1023/A:1010603732525

SCHOLZ, T.; KUCHTA, R.; SALGADO-MALDONADO, G. Cestodes of the family Dilepididae (Cestoda: Cyclophyllidea) from fisheating birds in Mexico: a survey of species. Systematic Parasitology, v. 52, n. 3, p. 171-182, 2002a. PMid:12143788. http://dx.doi. org/10.1023/A:1015700801579
SCHOLZ, T. et al. Larval tapeworms (Cestoda: Dilepididae) from the mummichog Fundulus heteroclitus (Linnaeus, 1766) and striped killifish Fundulus majalis (Walbaum, 1792) from South Caroline, U.S.A. Comparative Parasitology, v. 69, n. 1, p. 104-108, 2002b. http://dx.doi. org/10.1654/1525-2647(2002)069[0104:LTCDFT]2.0.CO;2

SCHOLZ, T. et al. Larvae of gryporhynchid cestodes (Cyclophyllidea) from fish: a review. Folia Parasitologica, v. 51, n. 2-3, p. 131-152, 2004

TAKEMOTO, R. M. et al. Diversity of parasites of fish from the upper Paraná river floodplain, Brazil. Brazilian Journal of Biology, v. 69, suppl. 2, p. 691-705, 2009. http://dx.doi.org/10.1590/S151969842009000300023 